\title{
RAC1 Activation as a Potential Therapeutic Option in Metastatic Cutaneous Melanoma
}

\author{
Paula Colón-Bolea ${ }^{1,+}$, Rocío García-Gómez ${ }^{1,2,+}$ (D) and Berta Casar $1,2, *$ (D) \\ 1 Instituto de Biomedicina y Biotecnología de Cantabria, Consejo Superior de Investigaciones \\ Científicas-Universidad de Cantabria, 39011 Santander, Spain; colonboleapaula@gmail.com (P.C.-B.); \\ rocio.garciagomez@unican.es (R.G.-G.) \\ 2 Centro de Investigación Biomédica en Red de Cáncer (CIBERONC), Instituto de Salud Carlos III, \\ 28029 Madrid, Spain \\ * Correspondence: casarb@unican.es \\ + These authors contribute equally to this work.
}

Citation: Colón-Bolea, P.;

García-Gómez, R.; Casar, B. RAC1

Activation as a Potential Therapeutic Option in Metastatic Cutaneous Melanoma. Biomolecules 2021, 11, 1554. https://doi.org/10.3390/ biom 11111554

Academic Editor: Mark S. Johnson

Received: 1 September 2021

Accepted: 15 October 2021

Published: 20 October 2021

Publisher's Note: MDPI stays neutral with regard to jurisdictional claims in published maps and institutional affiliations.

Copyright: (c) 2021 by the authors. Licensee MDPI, Basel, Switzerland. This article is an open access article distributed under the terms and conditions of the Creative Commons Attribution (CC BY) license (https:// creativecommons.org/licenses/by/ $4.0 /)$.

\begin{abstract}
Metastasis is a complex process by which cancer cells escape from the primary tumor to colonize distant organs. RAC1 is a member of the RHO family of small guanosine triphosphatases that plays an important role in cancer migration, invasion, angiogenesis and metastasis. RAC1 activation has been related to most cancers, such as cutaneous melanoma, breast, lung, and pancreatic cancer. RAC1P29S driver mutation appears in a significant number of cutaneous melanoma cases. Likewise, RAC1 is overexpressed or hyperactivated via signaling through oncogenic cell surface receptors. Thus, targeting RAC1 represents a promising strategy for cutaneous melanoma therapy, as well as for inhibition of other signaling activation that promotes resistance to targeted therapies. In this review, we focus on the role of RAC1 in metastatic cutaneous melanoma emphasizing the anti-metastatic potential of RAC1- targeting drugs.
\end{abstract}

Keywords: RAC1; cutaneous melanoma; invasion; metastasis; therapy resistance

\section{Introduction}

Melanoma is the most aggressive form of skin cancer representing more than $80 \%$ of deaths in cutaneous malignancies [1]. Metastasis is a complex process involving several steps, including migration, invasion, EMT (Epithelial-Mesenchymal Transition), angiogenesis, survival, plasticity and colonization of secondary tissues [2]. Metastatic cutaneous melanoma is a lethal disease with low survival rates, due to rapid acquisition of resistance to most available therapies [3].

Rho GTPases are important molecules that regulate cellular functions such as growth, motility, survival, migration, invasion, and metastasis thereby affecting tumor progression [4-7]. Rho GTPases are molecular switches that cycle between an active GTP and an inactive GDP bound form. RAC1 is one of the best characterized Rho GTPases that regulate crucial processes for melanoma tumorigenesis and metastasis. RAC1 activation is tightly regulated by activators, including guanine-nucleotide exchange factors (GEFs), and inhibitors, GTPase-activating proteins (GAPs) and guanine-nucleotide disassociation inhibitors (GDIs). In addition, RAC1 is regulated by modifications at its $\mathrm{C}$ terminus, including palmitoylation, carboxymethylation, and geranylgeranylation, as well as numerous post-translational modifications that influence its localization, activity, and ability to bind its effectors. RAC1 expression and activity are increased in human malignancies which in some cases correlates with aggressiveness and poor prognosis.

RAC1 signaling pathway is hyperactivated in human cancers and promotes tumor initiation, progression, and metastatic dissemination [8]. RAC1 point mutations and deregulated stability or subcellular localization have been identified as mechanisms that contribute to tumorigenesis and metastasis. Indeed, The Cancer Genome Atlas (TCGA) 
data shows that RAC1 is upregulated or mutated in over $10 \%$ of human cancers, including melanoma, glioblastoma, skin, esophageal, gastric, bladder, head and neck, liver, pancreatic, and prostate carcinomas $[9,10]$. RAC1P29S is the third most commonly mutated codon in human cutaneous melanoma, after BRAF V600 and NRAS Q61, and one of the most prominent driver mutations in RAC1 with a frequency of approximately $5 \%$ and up to $10 \%$ in chronically sun-exposed melanomas [11].

RAC1P29S mutation leads to gain of function and enhances binding to target proteins PAK1 and MAP3K11 (MLK3) activating downstream RAC1 signaling. RAC1P29S has a particular role in early transformation, enhancing cell migration and proliferation [12]. Moreover, this mutation confers resistance to RAF and MEK inhibitors, thus having significance in clinical therapeutic strategies [13]. Interestingly, expression of RAC1P29S in melanoma patients correlates with PD-L1 upregulation contributing to evading antitumor immune response and potentially serving as a predictive biomarker for therapy resistance in melanoma [14].

RAC1 has been implicated in RAS-induced neoplastic transformation. Moreover, malignant melanocytes have elevated RAC1 activity during migration, invasion and metastasis. It has been described that deregulation of GEFs, such as Dbl, Vav, Trio, Ect2, Tiam-1 and P-REX-1 also contribute to aberrant RAC1 signaling in many types of tumors [15-17].

In addition, RAC1 signaling can modulate cell motility and invasion through a variety of mechanisms such as promoting membrane protrusions and regulating focal adhesions. RAC1 activation has also been shown to regulate the mode of cell movement to promote colonization of tumor cells. Efficient regulation of RAC1 signaling may be required for cell -cell adhesion, tumor cell migration and invasion during metastasis. Inhibition of RAC1 activity could represent an opportunity to develop novel therapeutic approach to target different stages of tumor cell metastasis [18].

During tumor progression, a significant remodeling of the extracellular matrix (ECM) is evident [19]. RAC1 is involved in invadopodia-mediated ECM degradation [20]. RAC1 activation drives motility by regulating lamellipodia formation, focal adhesions and MMP expression [21].

The best-understood effectors for RAC1 are the p21-activated protein kinases (PAKs). PAKs regulate a multitude of cellular processes including cell motility, survival, proliferation, and organization of the cytoskeleton [22]. PAK1 is overexpressed in a subset of BRAF wildtype melanomas. RAC1 mutant human melanoma cells are resistant to clinical inhibitors of BRAF but are uniquely sensitive to PAK inhibitors [23].

RAC1 can be shuttled from the cytoplasm to the nucleus and abnormal localization, particularly in the nucleus, has been detected in cancer cells. In the nucleus, RAC1 can induce nuclear alterations through nuclear actin promoting nuclear plasticity during invasiveness [24]. Moreover RAC1 localization and activity can be regulated by scaffolding mechanisms. Temporal and spatial localization of RAC1 is tightly regulated by proteinprotein interactions $[25,26]$.

RAC1 signaling is also involved in angiogenesis and required for vertical blood vessel sprouting associated with tumor-induced angiogenesis [27]. RAC1 plays an important role in the development of resistance to anti-VEGF therapy, suggesting that the combination of VEGF/VEGFR-targeted therapies with a RAC1 inhibitor may improve the efficacy of the anti-metastasic therapies [28].

In this review, we focus on the role of RAC1 in cutaneous melanoma metastasis, advances in our understanding of key signaling pathways altered by activated RAC1, and its potential clinical therapeutic implications in metastatic cutaneous melanoma treatment. RAC1 hyperactivation plays an important role in regulating resistance to targeted therapies, as well as in the suppression of antitumor immune response, and this highlights the critical need to develop new therapeutic strategies to target RAC1 signaling (Figure 1). 


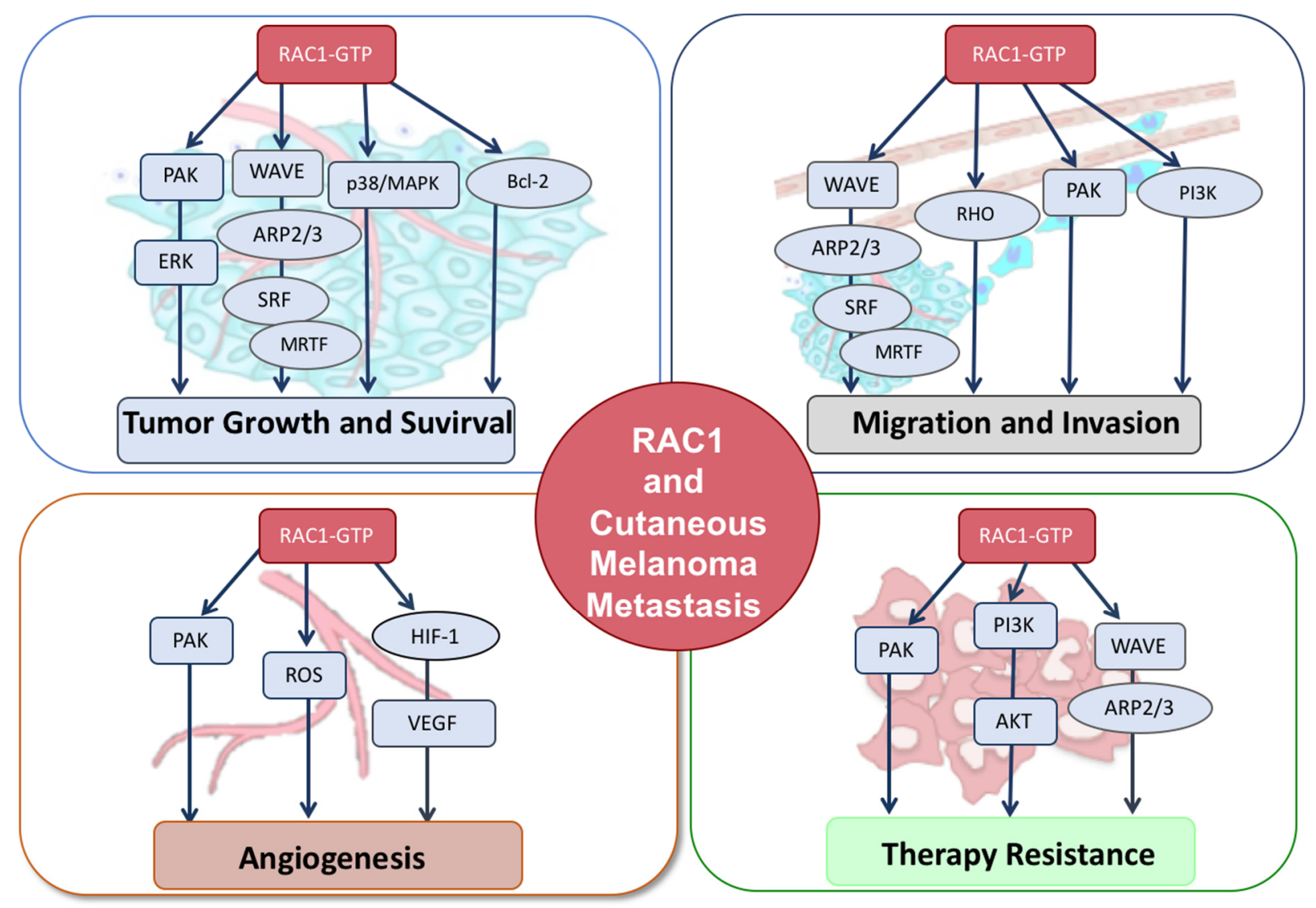

Figure 1. RAC1 signaling in metastatic cutaneous melanoma. Schematic diagram of RAC1 activation regulating tumor growth and survival, migration and invasion, angiogenesis and therapy resistance in cutaneous melanoma.

\section{RAC1 Pathway Activation in Melanoma Formation}

There is a growing body of evidence indicating that an enhanced activation of RAC1, either through its overexpression, its hyperactivation by GEFs or the appearance of the P29S mutation, contributes to cutaneous melanoma formation, often associated with activating mutations in BRAF or NRAS, or inactivating mutation of NF1 [13,14]. Although the exact downstream pathways by which RAC1 exerts its effects are still being unravelled, there are multiple studies pointing to possible mechanisms.

One of the possible signaling pathways of RAC1 in the promotion of melanoma is through its binding to Bcl-2. It has been shown that Bcl-2 phosphorylated at serine-70 (S70pBcl-2) confers apoptosis resistance to cancer cells [29]. Chong et al. described how RAC1-GTP binds to Bcl-2 leading to the accumulation of S70pBcl-2. Overexpression of RAC1 in melanoma cells increased ROS levels that inhibited PP2A preventing thereby dephosphorylation of Bcl-2. The authors describe a positive feedforward loop between RAC1-GTP and S70pBcl-2 sustaining an anti-apoptotic signaling in these cells [30].

In addition, RAC1P29S has been reported to increase the expression of PD-L1, not only with exogenous expression of RAC1P29S in vitro, but also with endogenous expression in melanoma patients. The exact mechanism by which the oncogene increases the levels of PD-L1 is still unknown, but the authors postulate that this increment helps melanomas to evade the immune system and thereby facilitates its growth [14].

A direct target protein of RAC1 is the lipid kinase phosphatidyl inositol-3 kinase (PI3K)- $\beta$ [31,32]. Indeed, treatment with selective inhibitors for PI3K $\beta$ in melanoma cell lines harboring the RAC1P29S mutation showed a decrease in proliferation [33]. Other PI3K selective inhibitors, including PI3K $\alpha, \delta$ and $\gamma$, appeared to be less effective. Another study relating AKT signaling to survival described how melanocytes with endogenous RAC1P29S had a higher survival rate when cultured in the absence of growth factors or 
in an anchorage-independent condition. With the use of siRNA and small molecules, the authors were able to associate these events to AKT signaling [34].

RAC1P29S can induce ERK phosphorylation in melanocytes [9]. This capacity of activating MAPK pathway also plays a role in protecting melanoma cells with $R A C 1$ and $B R A F$ mutations from apoptosis when treated with RAF inhibitors. The authors claim that RAC1P29S sustained the levels of pMEK and pERK in the presence of inhibitors and that these levels decreased following RAC1P29S knockdown [13]. In line with the role of RAC1 in this MAPK pathway are the PAKs, one of the best characterized effectors for RAC1 [22]. These proteins promote, among other processes, cell survival and proliferation by phosphorylating different substrates. PAKs have been described as key components of the ERK pathway, not only due to their kinase activity (they are able to phosphorylate cRAF at S338 and MEK1 at S298), but also to their scaffolding function [35]. Inhibiting PAKs function with Frax-1036 in melanoma cells harboring RAC1P29S mutation, resulted in marked reduction of proliferation and viability. These results were corroborated in in vivo xenograft experiments [23]. Lionarons et al. also described decreased proliferation after genetically inhibiting PAK in their animal model [34]. These results point to a RAC1-PAKMEK-ERK pathway in the formation of melanoma.

In this last study, the authors also identified another signaling pathway related to the promotion of survival in melanocytes and melanoma cells, independent of PAK or AKT. RAC1P29S activates a WAVE-ARP2/3-SRF/MRTF cascade that triggers a transcriptional program switching the cells to a mesenchymal phenotype characterized by resistance to apoptosis.

\section{RAC1 Signaling in Tumor Cell Migration and Invasion}

Cell migration is required for many processes such as embryogenesis or wound healing, but when deregulated it contributes to dissemination of cancer metastases. Melanoma cells can invade not only the dermis, but also other organs such as the lungs, the liver or the brain [36]. RAC1, as a pivotal regulator of the cytoskeleton, plays a main role in this process. It drives motility by promoting among others, lamellipodia formation, focal adhesions and MMP expression [37].

Tumor cells can switch between two different modes of movement. RAC1 is responsible for directing mesenchymal movement, characterized by an elongated cellular morphology and the requirement of extracellular proteolysis. Sanz-Moreno et al. discovered that when activated, RAC1 suppressed RHOA dependent amoeboid movement through decreasing actomyosin contractility. An important RAC1 effector is WAVE2, a member of the WASP-family verprolin-homologous proteins. These proteins regulate the actin cytoskeleton and therefore have an important role in cell migration and invasion. The authors were able to trace decrease in phosphorylation of Myosin Light Chain (MLC) to WAVE2 [38]. Another study pointing to the importance of WAVE2 as a RAC1 effector, described how in mouse melanoma cells with ectopic overexpression of constitutive active RAC1, there was an increase in invasiveness that was reverted by WAVE2 RNAi [39]. Regulation of the cytoskeleton by WAVEs takes place through the activation of the actin nucleation complex ARP2/3 [40] which in turn leads to the activation of SRF/MRTF inducing a transcription program in melanocytes that leads to mesenchymal transition [34].

Another pathway regulated by RAC1 that plays an important role in melanoma is PI3K-AKT, which has also been described to play a role in EMT [41] and migration [42,43]. PI3K -RAC1 activation regulates EMT in melanoma cells and promotes metastasis.

Regarding MMP expression, there is a study that relates MMP-2 to RAC1 in melanoma cells. The authors saw how P-REX1 (PIP3-dependent RAC exchange factor-1), a guanine nucleotide exchange factor that activates RAC1, regulated cell migration and invasion. Cells bearing overexpression of P-REX1 had increased RAC1-GTP, p-PAK1, p-p38 and MMP-2 levels. To further confirm their results, they used RAC1 and p38 inhibitors in control cells and in P-REX1 knockdown cells. Control cells exhibited a pronounced inhibition in migration and invasion, whereas P-REX1 knockdown cells showed no changes. These 
results highlight the importance of the P-REX1/RAC1/PAK1/p38/MMP-2 pathway in migration and invasion of melanoma cells [43].

RAC1 regulation of invadopodia in melanoma is controversial. Revach et al. observed how expression of wildtype RAC1 in cells led to invadopodia formation, whereas RAC1P29S harbouring cells, with higher migration rate, showed suppressed invadopodia and matrix degradation, but enhanced lamellipodia formation. These confusing results point to different signaling pathways for wildtype and mutant RAC1. Disassembly of invadopodia has been related to a TRIOGEF-RAC1-PAK1-cortactin pathway [44]. Increased number of lamellipodia in melanoma cells expressing mutant RAC1 compared to wildtype has also been described by Mohan et al. [45]. In this study the authors describe how RAC1P29S induced an enhanced lamellipodial branched actin network conferring the cells higher migration and the ability to sequester and phosphoinactivate Merlin, a tumor suppressor known to downregulate cyclin D1 and prevent cell cycle progression [46]. Interestingly, the authors demonstrate how for the inactivation of Merlin, both PAK activation and the branched actin polymerization driven by mutated RAC1, are necessary. RAC1 through PAK1, Merlin and the cytoskeleton renders the melanoma cells a higher metastatic potential and higher proliferation rate of metastatic cells.

RAC1 not only exerts its pro-metastatic effect through the actin cytoskeleton, but also through its ability to act on the microtubule cytoskeleton. We showed how through PAK1, constitutive active RAC1 acted on the microtubules, and through the Linker of Nucleoskeleton and Cytoskeleton (LINC) complex, connected to the nucleoskleton and induced nuclear plasticity. This allowed the cells to pass through smaller pores and promoted a more invasive phenotype. Disrupting the LINC complex prevented melanoma cells from undergoing invasion [47].

\section{RAC1 Signaling in Angiogenesis}

Angiogenesis, the process by which the formation of new blood vessels arising from pre-existing vasculature occurs, is essential for tumour growth and dissemination [48]. This neovascularization is crucial to maintain oxygen and nutrients supply, and it might serve tumoral cells as a path to colonize distant organs.

Capillary formation is tightly controlled by a pro- and anti- angiogenic factors balance, yet this changes during tumour progression, where the scale tilts towards a pro-angiogenic outcome (angiogenic switch) [49], which ultimately regulates endothelial cells proliferation, survival and migration [50]. Some molecules have been highlighted as pro-angiogenic factors during tumour progression, such as RAC1, MMPs, TIMP, and NCK1 [51].

Although other Rho family members are also involved in cancer-related angiogenesis, RAC1 has been proven to be essential in this process, since its activation controls endothelial cell morphogenesis and motility to form a lumen [52,53]. Accordingly, RAC1 endothelial deletion leads to embryonic mortality [54] as a consequence of defects in major vessel formation and absence of small branched vessels, due to cell migration impairment likely mediated by an F-actin dependent mechanism [55].

Moreover, RAC1 is crucial to coordinate endothelial cell-cell adhesion into vessel structures during capillary formation [56]. Hence, with dominant-negative RAC1 mutants, vascular endothelial cells are unable to endure the morphogenic modifications needed for capillary organization, whilst RHO and CDC42 do not affect the same processes [57].

For a blood vessel to form, Matrix Metalloproteases (MMPs) are required to degrade and remodel the vascular basement membrane and ECM, which in turn allows endothelial cell migration and invasion into the surrounding tissue [58]. During this process proangiogenic factors such as Vascular Endothelial Growth Factor (VEGF), Transforming Growth Factor-Beta (TGF- $\beta$ ) and others are released, activating a downstream signaling cascade involving RAC1 [59].

Hypoxia enhances RAC1 activity in cancer cells [60], which in turn is required for HIF1 accumulation [61-63]. Additionally to being downstream of VEGF, under hypoxic conditions, there is a positive feedback loop where RAC1 can also upregulate VEGF and 
other angiogenic factors expression, such as Nitric Oxide Synthase (NOS), Platelet-Derived Growth Factor-Beta (PDGF- $\beta$ ) and Ang-2 in a HIF1-dependent manner [64]. Thus, RAC1 overexpression is associated with high levels of VEGF and Vascular Endothelial Growth Factor Receptor (VEGFR) [65]; whereas its downregulation in vascular endothelial cells causes VEGF-mediated tube formation impairment as well as cell migration, invasion and proliferation inhibition in vitro [66].

RAC1 is also able to modulate VEGF by promoting Reactive Oxygen Species (ROS) production via $\mathrm{NAD}(\mathrm{P}) \mathrm{H}$ oxidase in vascular cells [67]. Then, VEGF binds VEGFR2 whose phosphorylation in turn activates downstream signalling molecules such as ERK1/2, Akt and ROS.

Moreover, it has been demonstrated that IQ motif containing GTPase Activating Protein 1 (IQGAP1), a scaffold protein that harbours a RAC1 binding domain, binds directly to VEGFR, mediating ROS-dependent endothelial migration and proliferation [68], while IQGAP1 knock-out prevents choroidal neovascularization caused by the VEGFR2-RAC1 signalling axis [69].

PAKs have been found to be essential angiogenesis regulators [22], helping in mouse post-stroke recovery [70]. In this regard, the RAC1-PAK1 pathway has been demonstrated to be involved in anti-VEGF (Bevacizumab) and anti-VEGFR (Sunitinib) drug resistance, since its inhibition lessens stem cell properties and overcomes therapy resistance in prostate cancer [28].

Despite being a promising therapeutical target, the usage of anti-angiogenic compounds in cancer clinical trials yielded disappointing results [71]. Targeted therapy against RAC1 and its associated signalling pathways needs to be further investigated as it may prove useful in human diseases involving anomalous vasculature formation and solid tumour treatment.

\section{RAC1 Targeting Therapies and Therapy Resistance}

The identification of RAC1P29S substitution as the third most recurrently observed activating mutation in cutaneous melanoma [72], has opened new therapeutic opportunities. Nevertheless, like other small GTPases, to target RAC1 protein itself turns out challenging. Even so, other therapeutical strategies have been used to treat tumours bearing this signature, such as: preventing RAC1 localization at the plasma membrane, hampering GTP binding, blocking GEF/RAC1 interaction or targeting its effector molecules (Figure 2, Table 1) [10].

Table 1. Compounds developed targeting RAC1.

\begin{tabular}{|c|c|c|c|c|}
\hline Compound Name & Structure & Target & Mechanism of Action & References \\
\hline \multicolumn{5}{|c|}{ Blocking GEF/RAC1 Interactions } \\
\hline $1 \mathrm{~A}-116$ & & p-REX & $\begin{array}{c}\text { Blocks RAC-p-REX1 } \\
\text { interaction, reducing } \\
\text { intracellular RAC1-GTP } \\
\text { levels. }\end{array}$ & [73] \\
\hline ТВОРР & & DOCK1 & $\begin{array}{c}\text { Binds to the DOCK1 } \\
\text { DHR-2 domain, inhibiting } \\
\text { DOCK1-mediated RAC } \\
\text { activation. }\end{array}$ & [74] \\
\hline EHop-016 & & VAV2 & $\begin{array}{c}\text { Prevents RAC1-VAV2 } \\
\text { association, inhibiting } \\
\text { activity of RAC } \\
\text { downstream effector PAK1. } \\
\text { It also targets CDC42. }\end{array}$ & {$[75,76]$} \\
\hline
\end{tabular}


Table 1. Cont.

\begin{tabular}{|c|c|c|c|c|}
\hline Compound Name & Structure & Target & Mechanism of Action & References \\
\hline Compound 4 & & VAV2, TIAM1, TRIO & $\begin{array}{l}\text { Impedes RAC1 binding to } \\
\text { TIAM1, TRIO and VAV2. }\end{array}$ & {$[77,78]$} \\
\hline NSC23766 & & TIAM1, TRIO & $\begin{array}{l}\text { Inhibits RAC1 binding and } \\
\text { activation by the } \\
\text { RAC-specific GEFs TRIO or } \\
\text { TIAM1. }\end{array}$ & [79] \\
\hline ITX3 & & TRIO-N & $\begin{array}{l}\text { Inhibits TRIO N-terminal } \\
\text { GEF domain, reducing } \\
\text { RAC1 and RHOG } \\
\text { activation. }\end{array}$ & [80] \\
\hline ZINC69391 & & TIAM1 & $\begin{array}{l}\text { Interferes RAC1-TIAM1 } \\
\text { interaction, reducing } \\
\text { RAC1-GTP levels. }\end{array}$ & [73] \\
\hline ZINC08010136 & & TIAM1 & $\begin{array}{c}\text { Disrupts RAC1-TIAM1 } \\
\text { complex, decreasing active } \\
\text { RAC1 cytoplasmic levels } \\
\text { without affecting RHOA } \\
\text { and CDC42. It is four times } \\
\text { more effective than } \\
\text { NSC23766. }\end{array}$ & [81] \\
\hline ZINC07949036 & & TIAM1 & $\begin{array}{l}\text { Blocks RAC1-TIAM1 } \\
\text { interaction without } \\
\text { affecting RHOA and } \\
\text { CDC42 activation. }\end{array}$ & [81] \\
\hline \multicolumn{5}{|c|}{ Lessening RAC1-GTP Coupling } \\
\hline DA-MED & & RAC1 & $\begin{array}{l}\text { RAC1 agonist. It has been } \\
\text { shown to induce ROS } \\
\text { production. }\end{array}$ & [82] \\
\hline EHT-1864 & $\mathrm{H}-\mathrm{Cl}$ & RAC1 & $\begin{array}{c}\text { Inhibits RAC family } \\
\text { GTPases. Blocking its } \\
\text { activation by direct } \\
\text { binding to RAC1, RAC1b, } \\
\text { RAC2 and RAC3. }\end{array}$ & [83] \\
\hline \multicolumn{5}{|c|}{ Hampering RAC1 Localization } \\
\hline GGTI-2418 & & eranylgeranyl transferase 1 & $\begin{array}{l}\text { Inhibits GGTase I, in charge } \\
\text { of lipid modification } \\
\text { required for RAC function. }\end{array}$ & {$[84]$} \\
\hline Simvastatin & & HMG-CoA reductase & $\begin{array}{c}\text { Inhibits isoprenoid } \\
\text { synthesis, reducing RAC1 } \\
\text { membrane association and } \\
\text { activity. }\end{array}$ & [85] \\
\hline PATi & & PATs & $\begin{array}{c}\text { Inhibits Palmitoyl } \\
\text { Acyltransferases (PATs), } \\
\text { interfering with RAC1 } \\
\text { localization. }\end{array}$ & [86] \\
\hline
\end{tabular}


Table 1. Cont.

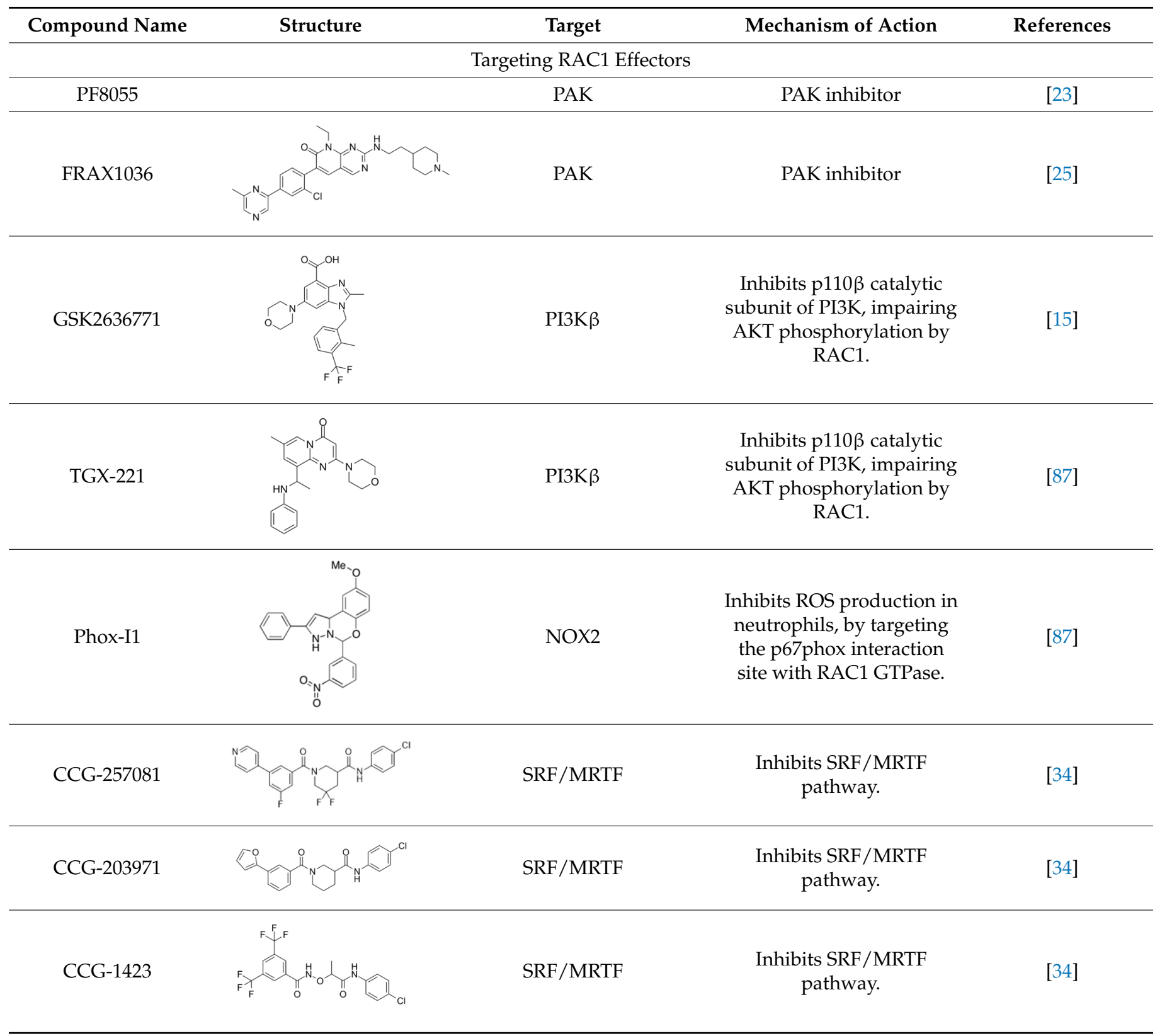

\subsection{Preventing RAC1 Localization}

To exert its biological activities RAC1 requires membrane targeting, being this association achieved via carboxyl-terminal lipid modifications. Regarding its plasma membrane translocation, it is mediated by geranylgeranyl transferases type I (GGTI) that trigger RAC1 prenylation [84].

Owing to the importance of post-translational modifications mediating RAC1 subcellular localization and activation, several compounds able to block these lipid modifications have been developed. Among them, GGTI inhibitors have demonstrated promising in vitro and preclinical outcomes [86], exerting anti-tumorigenic effects in human pancreatic and non-small cell lung cancer xenograft mouse models $[88,89]$. Conversely, in some cell types, it has been shown that GGTI blockade activates RAC1 [90]; this could be a plausible explanation for the inefficacy shown by GGTI2418 in clinical trials [91]. 


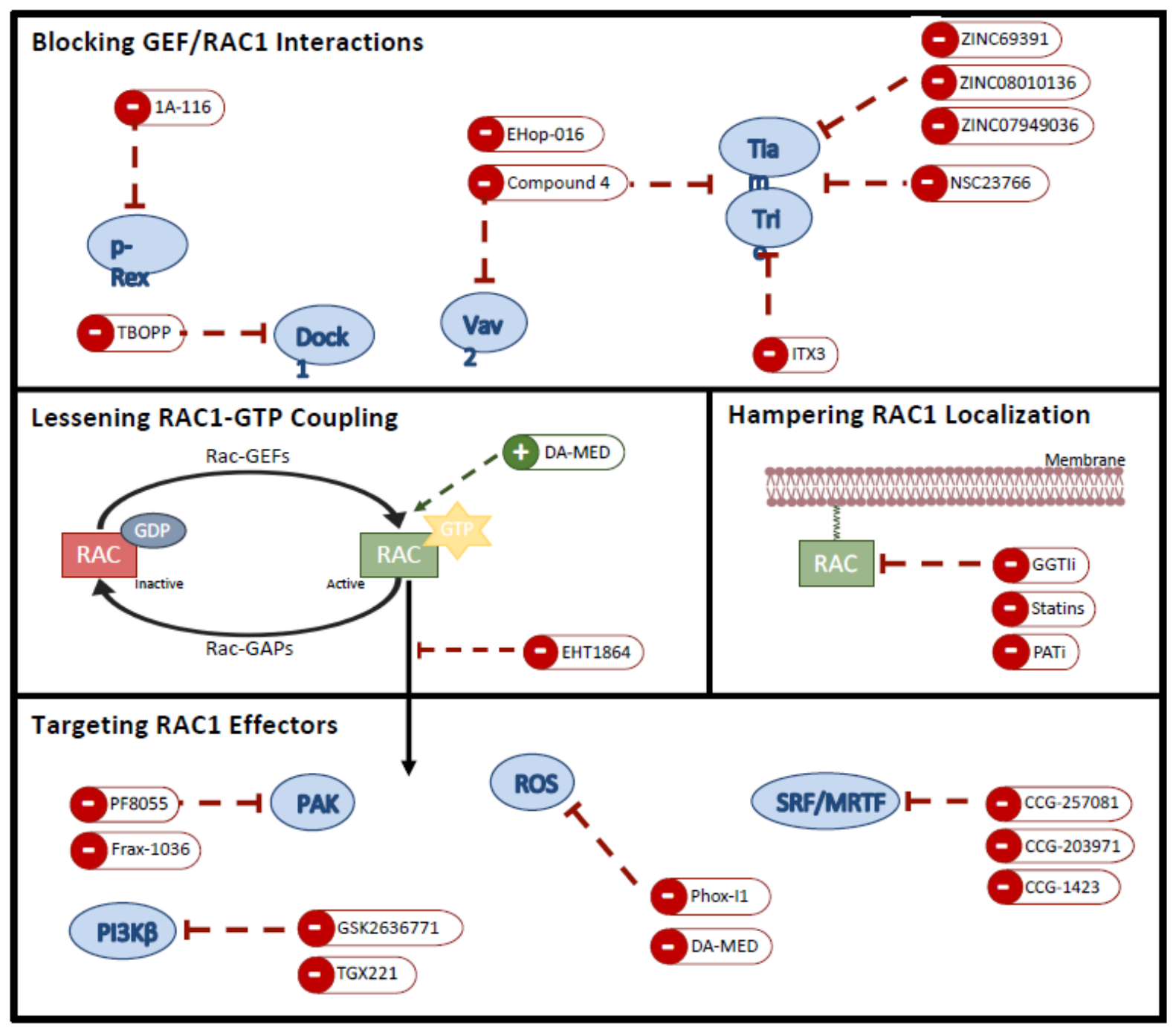

Figure 2. Targeting RAC1 in metastatic cutaneous melanoma. Current available inhibitors to target RAC1 pathway by blocking GEF-RAC1 interactions, lessening nucleotide binding, hampering RAC1 localization as well as by inhibiting downstream effector activity.

Impairing isoprenoid synthesis by using statins to block HMG-CoA reductase also reduces RAC1 membrane association and activity [85]. In this regard, Simvastatin represses RAC1-dependent MMP-1 production and reduces RAC1 GTP-bound levels [92]. It has been shown that with the mode of action of prenylation-independent statins the observed effects would be due to nuclear RAC1 degradation [93].

Prenylation prepares RAC1 for S-palmitoylation, which is mediated by Palmitoyl Acyltransferases (PATs), enhancing its stability and membrane association. In fact, RAC1 palmitoylation inhibition interferes with its localization and suppresses RAC1-mediated cell migration [86,94]. Several PAT inhibitors have been developed $[61,62]$ and their usage has been shown to increase RAC1 perinuclear localization whilst decrease RAC1 GTP content.

Nevertheless, due to prenylation and palmitoylation, key roles modulating protein localization and activity, it is necessary to further investigate the consequences of RAC1 inhibition.

\subsection{Hampering Nucleotide Coupling}

RAC1 binding to GTP causes its activation, inducing conformational changes that allow attachment of downstream effectors [63]. EHT-1864 is an inhibitor of the Rac family GTPases and blocks activation by direct binding to all RAC isoforms [83]. Critically, it 
has been shown to block RAC1-mediated transformation [64], although it has also shown off-target effects [83].

\subsection{Blocking GEF/RAC1 Interactions}

Considering GEFs key role coordinating RAC1 signalling and the benefit of inhibiting certain RAC1 functions, blocking GEF-RAC1 interactions represents an interesting therapeutic option.

NSC23766, the first selective RAC1-GEF blocking agent discovered, inhibits RAC1 interaction with TIAM1 and TRIO [79], countering RAC1 tumorigenic effects in several cancer models [5]. Regardless of its effects, NSC23766 potency is not sufficient to use it in clinical applications [95]. This encouraged in silico screening approaches to look for more potent RAC1-GEF inhibitors, leading to the discovery of ZINC08010136 and ZINC07949036 molecules that block RAC1-TIAM1 interaction without affecting RHOA and CDC42 activation [81]. Another inhibitor that was identified, known as "Compound 4", impeded RAC1 binding to TIAM1, TRIO and VAV2 [77]. This compound has demonstrated to repress cell adhesion and RAC1-mediated cellular events as well as RAC1-PDGF $\beta$ mediated lamellipodia formation [78].

ZINC69391, another virtually screened RAC1-GEF blocking agent, impedes RAC1TIAM1 binding and efficiently inhibits highly metastatic breast cancer cell proliferation, cycle progression and migration, showing anti-metastatic effects in mouse models. A more potent ZINC69391 analog, 1A-116, that blocks RAC1-REX1 interaction, has shown anti-metastatic effects in breast cancer models [73].

ITX3 is another blocking agent that impedes RAC1-TRIO binding, although it is not a good candidate for clinical designs due to its low potency [80].

EHop-016, discovered by optimization of NSC23766 chemical structure, prevents RAC1-VAV2 binding suppressing RAC1-driven migration of metastatic cancer cells [75]. Nevertheless, these effects could be due to its promiscuity as this compound has also been proven to lessen PAK1 activation and to target CDC42 [76].

Another NSC23766 derivative, MBQ-167, has demonstrated deep growth inhibition of xenografted breast cancer cells [96].

Moreover, RAC1-DOCK1 binding blockade genetically or pharmacologically, by using TBOPP, has demonstrated to cancel RAC1P29S nucleotide exchange and to lessen melanoma and breast cancer matrix invasion [74].

\subsection{Targeting RAC1 Effectors}

Regardless of attempts to target RAC1 activators or RAC1 itself, inhibition of specific RAC1-effector interactions is, to date, the most effective and direct approach for blocking RAC1 outcomes without affecting other downstream signalling pathways.

Among these effectors, the best described druggable RAC1 effectors are the PAKs, which take part in ERK, $\beta$-catenin, Aurora A and Merlin activation. In these regards, PAK inhibitors have shown sensibilization of RAC1P29S mutant melanoma cell lines and xenografts [23]. Considering PAK2 key role in cardiac function, its clinical application is questionable; nevertheless, PAK1 inhibitors might be refined for RAC1-driven cancer treatment [97].

Therapeutic potential of RAC1-mediated ROS production inhibition pushed the hunt for RAC1-p67phox interaction inhibitors, such as Phox-I1 that has been shown to inhibit ROS generation in neutrophils [98]. In addition, a RAC1 agonist, called Deacetylepoxydiene (DA-MED), has been developed and its usage induced apoptosis in NSCLC cells due to a huge production of ROS 2 [82].

Activation of SRF/MRTF transcriptional circuit and WAVE2/ARP2/3 actin axis triggered by RAC1P29S, induces a melanocytic to mesenchymal swap and actin filaments organization that, in turn, facilitates cell migration and metastasis. This way, MRTF depletion or use of SRF/MRTF inhibitors (CCG-1423 and CCG-203971) in melanoma cells abolished melanocytic to mesenchymal transition and PLX4720 co-treatment with CCG- 
257081 overcame tumour growth in mice [34]. However, SRF/MRTF inhibitors mechanism of action is unknown as they have been shown to bind Pirin [99] a transcription factor implicated in melanoma cells senescence, migration and progression [100,101]. Moreover, actin nucleation and/or polymerization inhibition, for example targeting ARP2/3 or formins, could be used in the treatment of RAC1 mutant tumours [45].

Regarding the PI3K network, RAC1 activates AKT by selectively interacting with PI3K $\beta$ [31]. Considering that selective PI3K $\beta$ inhibitors were able to prevent melanoma cell proliferation and migration driven by mutant RAC1 but not by mutant BRAF, whilst PI3K $\alpha$ inhibitors had the opposite effect [87]; and restricted PI3K inhibitors activity in RAC1P29S melanocytes [34], it would be interesting to further investigate PI3K inhibitors.

Overall, it has been proven the therapeutical advantage of targeting specific RAC1effector interactions, while the development of more potent inhibitors that selectively target RAC1 signalling cascades is still necessary.

\subsection{Therapy Resistance}

Cancer therapy efficiency has considerably improved thanks to the usage of molecularly targeted drugs. Nonetheless, the main cause of cancer relapse is the appearance of drug resistance which notably lessens treatment efficacy and even drives it to failure.

Evidence from a clinical study of 45 melanoma patients [102] pointed out RAC1P29S status as a vemurafenib and dabrafenib resistance marker that might help to prognosticate patients response to targeted therapy. Moreover, it has been demonstrated that mutant RAC1 can cause ERK phosphorylation in melanocytes [9] and support MAPK signalling in the presence of RAF inhibitors, as overexpression of mutant RAC1P29S in A375 cells raised phosphor-MEK1/2 levels in presence of dabrafenib, thus conferring resistance to MAPK inhibitors in vitro $[13,34]$.

RAC1P29S triggers the PAK, AKT and WAVE-ARP2/3-SRF/MRTF signalling cascade, inducing a switch from a melanocytic to a mesenchymal-like behavior. As a result, melanoma cells acquire improved tumorigenic capacities due to apoptosis suppression and BRAF inhibitor resistance [34]. In the last few years some SRF/MRTF inhibitors have arisen $[103,104]$ and been used in several preclinical models [105]. In this regard, these molecules could be used in the clinic together with BRAF inhibitors to address melanoma resistance [95].

Regarding immune therapy resistance, whereas PD-L1 expression has been demonstrated to be a poor prognostic factor for malignant melanoma [106], Vu et al. [14] found PD-L1 to be upregulated when RAC1P29S was expressed, whereas it was downregulated when RAC1P29S was depleted. Moreover, using melanoma patient samples in TCGA, they identified a positive correlation between PD-L1 expression and RAC1P29S status when compared to wildtype and other RAC1 mutants. These observations suggest that RAC1P29S mutation could be promoting an antitumoral immune response suppression [14].

Therefore, it may be valuable to evaluate clinically RAC1 mutational signature as a predictive biomarker for MEK/RAF inhibitor and anti-PD-1 and PD-L1 therapy resistance in melanoma patients.

Eventually, considering the latest boost in the development of RAS-targeting inhibitors, it isn't unthinkable that direct inhibitors for mutant RAC1 could arise. Those therapies would attempt avoiding the appearance of drug resistance related to RAC1 mutations, procuring a new molecular weaponry against cancer.

\section{Conclusions and Perspectives}

An overwhelming body of data indicates that RAC1 is involved in tumorigenesis, proliferation, metastatic dissemination as well resistance to targeted therapies. Thus, the identification of RAC1 driver mutations in melanoma opened new therapeutic avenues for metastatic melanoma treatment, highlighting the need for the development of potential drugs to support personalized treatment approaches based on RAC1 inhibition. 
Interestingly, the last studies indicated the role of RAC1 activation in oncogenic signaling through some expected effectors, such as the PAKs, and new candidates like SRF/MRTF, which highlights an important link between actin cytoskeleton and oncogenic transcriptional events. These findings suggest new therapeutic strategies to treat cancers driven by this mutation. However, because neither PAK and SRF/MRTF inhibitors are currently in clinical trials, there is still much work to do to translate these findings into the clinic.

In addition, it has been described that there is a correlation between mutant RAC1 and PD-L1 expression, indicating that the potential use of RAC1 inhibitors in combination with anti-PD/PD-L1 antibodies or other agents that facilitate antitumor immune responses, could represent one potential treatment for melanoma. However, additional studies would be required to check the effectiveness of RAC1 inhibitors as a new immunotherapy treatment for melanoma.

Future work will need to determine the role of RAC1 in therapeutic resistance, and the possibility of blocking RAC1 signaling inhibiting specific GEFs, and direct effectors, such as PAK, PI3K, and specific proteins that regulate actin polymerization. Moreover, further studies might be done to develop direct inhibitors of mutant RAC1.

In summary, the overwhelming data argues for the important roles of the RAC1 signaling pathway in every aspect of cancer progression. The aberrant activity of RAC1, RAC-GEFs, and RAC1 effectors in cancer, together with their involvement in metastasis and therapy resistance, emphasize the rich therapeutic opportunities afforded by inhibition of the RAC1 pathway and will translate into benefits for metastatic melanoma patients in a clinical setting.

Author Contributions: P.C.-B., R.G.-G. and B.C. jointly prepared the manuscript. All authors have read and agreed to the published version of the manuscript.

Funding: B.C. lab is supported by PIE grant (PIE-202020E007) from Consejo Superior de Investigaciones Científicas (CSIC)- MCIU, Ramón y Cajal Research Program (MCIU, RYC2018-024004-I), and MCIN grant (PID2020-112760RB-I00).

Institutional Review Board Statement: Not applicable.

Informed Consent Statement: Not applicable.

Data Availability Statement: Not applicable.

Conflicts of Interest: The authors declare no conflict of interest.

\section{References}

1. Hodi, F.S.; O’Day, S.J.; McDermott, D.F.; Weber, R.W.; Sosman, J.A.; Haanen, J.B.; Gonzalez, R.; Robert, C.; Schadendorf, D.; Hassel, J.C.; et al. Improved survival with ipilimumab in patients with metastatic melanoma. N. Engl. J. Med. 2010, 363, 711-723. [CrossRef]

2. Welch, D.R.; Hurst, D.R. Defining the Hallmarks of Metastasis. Cancer Res. 2019, 79, 3011-3027. [CrossRef]

3. Greene, F.L.; Sobin, L.H. The staging of cancer: A retrospective and prospective appraisal. CA Cancer J. Clin. 2008, 58, 180-190. [CrossRef] [PubMed]

4. Vega, F.M.; Ridley, A.J. Rho GTPases in cancer cell biology. FEBS Lett. 2008, 582, 2093-2101. [CrossRef] [PubMed]

5. Bid,H.K.; Roberts, R.D.; Manchanda, P.K.; Houghton, P.J. RAC1: An emerging therapeutic option for targeting cancer angiogenesis and metastasis. Mol. Cancer Ther. 2013, 12, 1925-1934. [CrossRef] [PubMed]

6. Moshfegh, Y.; Bravo-Cordero, J.J.; Miskolci, V.; Condeelis, J.; Hodgson, L. A Trio-Rac1-Pak1 signalling axis drives invadopodia disassembly. Nat. Cell Biol. 2014, 16, 574-586. [CrossRef] [PubMed]

7. Maldonado, M.D.M.; Dharmawardhane, S. Targeting Rac and Cdc42 GTPases in Cancer. Cancer Res. 2018, 78, 3101-3111. [CrossRef] [PubMed]

8. Olson, M.F. Rho GTPases, their post-translational modifications, disease-associated mutations and pharmacological inhibitors. Small GTPases 2018, 9, 203-215. [CrossRef]

9. Krauthammer, M.; Kong, Y.; Ha, B.H.; Evans, P.; Bacchiocchi, A.; McCusker, J.P.; Cheng, E.; Davis, M.J.; Goh, G.; Choi, M.; et al. Exome sequencing identifies recurrent somatic RAC1 mutations in melanoma. Nat. Genet. 2012, 44, 1006-1014. [CrossRef] [PubMed] 
10. Davis, M.J.; Ha, B.H.; Holman, E.C.; Halaban, R.; Schlessinger, J.; Boggon, T.J. RAC1P29S is a spontaneously activating cancerassociated GTPase. Proc. Natl. Acad. Sci. USA 2013, 110, 912-917. [CrossRef] [PubMed]

11. Porter, A.P.; Papaioannou, A.; Malliri, A. Deregulation of Rho GTPases in cancer. Small GTPases 2016, 7, 123-138. [CrossRef]

12. Mar, V.J.; Wong, S.Q.; Logan, A.; Nguyen, T.; Cebon, J.; Kelly, J.W.; Wolfe, R.; Dobrovic, A.; McLean, C.; McArthur, G.A. Clinical and pathological associations of the activating RAC1 P29S mutation in primary cutaneous melanoma. Pigment Cell Melanoma Res. 2014, 27, 1117-1125. [CrossRef] [PubMed]

13. Watson, I.R.; Li, L.; Cabeceiras, P.K.; Mahdavi, M.; Gutschner, T.; Genovese, G.; Wang, G.; Fang, Z.; Tepper, J.M.; Stemke-Hale, K.; et al. The RAC1 P29S hotspot mutation in melanoma confers resistance to pharmacological inhibition of RAF. Cancer Res. 2014, 74, 4845-4852. [CrossRef] [PubMed]

14. Vu, H.L.; Rosenbaum, S.; Purwin, T.J.; Davies, M.A.; Aplin, A.E. RAC1 P29S regulates PD-L1 expression in melanoma. Pigment Cell Melanoma Res. 2015, 28, 590-598. [CrossRef] [PubMed]

15. Lindsay, C.R.; Li, A.; Faller, W.; Ozanne, B.; Welch, H.; Machesky, L.M.; Sansom, O.J. A Rac1-independent role for P-Rex1 in melanoblasts. J. Investig. Dermatol. 2015, 135, 314-318. [CrossRef] [PubMed]

16. Cook, D.R.; Rossman, K.L.; Der, C.J. Rho guanine nucleotide exchange factors: Regulators of Rho GTPase activity in development and disease. Oncogene 2014, 33, 4021-4035. [CrossRef]

17. Wertheimer, E.; Gutierrez-Uzquiza, A.; Rosemblit, C.; Lopez-Haber, C.; Sosa, M.S.; Kazanietz, M.G. Rac signaling in breast cancer: A tale of GEFs and GAPs. Cell Signal 2012, 24, 353-362. [CrossRef]

18. Mack, N.A.; Whalley, H.J.; Castillo-Lluva, S.; Malliri, A. The diverse roles of Rac signaling in tumorigenesis. Cell Cycle 2011, 10, 1571-1581. [CrossRef]

19. Brassart-Pasco, S.; Brézillon, S.; Brassart, B.; Ramont, L.; Oudart, J.; Monboisse, J. Tumor Microenvironment: Extracellular Matrix Alterations Influence Tumor Progression. Front. Oncol. 2020, 10, 397. [CrossRef]

20. Revach, O.Y.; Winograd-Katz, S.E.; Samuels, Y.; Geiger, B. The involvement of mutant Rac1 in the formation of invadopodia in cultured melanoma cells. Exp. Cell Res. 2016, 343, 82-88. [CrossRef]

21. Jaffe, A.B.; Hall, A. Rho GTPases: Biochemistry and biology. Annu. Rev. Cell Dev. Biol. 2005, 21, 247-269. [CrossRef]

22. Radu, M.; Semenova, G.; Kosoff, R.; Chernoff, J. PAK signalling during the development and progression of cancer. Nat. Rev. Cancer 2014, 14, 13-25. [CrossRef] [PubMed]

23. Araiza-Olivera, D.; Feng, Y.; Semenova, G.; Prudnikova, T.Y.; Rhodes, J.; Chernoff, J. Suppression of RAC1-driven malignant melanoma by group A PAK inhibitors. Oncogene 2018, 37, 944-952. [CrossRef] [PubMed]

24. Navarro-Lerida, I.; Pellinen, T.; Sanchez, S.A.; Guadamillas, M.C.; Wang, Y.; Mirtti, T.; Calvo, E.; Del Pozo, M.A. Rac1 nucleocytoplasmic shuttling drives nuclear shape changes and tumor invasion. Dev. Cell 2015, 32, 318-334. [CrossRef] [PubMed]

25. van Duijn, T.J.; Anthony, E.C.; Hensbergen, P.J.; Deelder, A.M.; Hordijk, P.L. Rac1 recruits the adapter protein CMS/CD2AP to cell-cell contacts. J. Biol. Chem. 2010, 285, 20137-20146. [CrossRef]

26. Nouri, K.; Fansa, E.K.; Amin, E.; Dvorsky, R.; Gremer, L.; Willbold, D.; Schmitt, L.; Timson, D.J.; Ahmadian, M.R. IQGAP1 Interaction with RHO Family Proteins Revisited: KINETIC AND EQUILIBRIUM EVIDENCE FOR MULTIPLE DISTINCT BINDING SITES. J. Biol. Chem. 2016, 291, 26364-26376. [CrossRef]

27. Nohata, N.; Uchida, Y.; Stratman, A.N.; Adams, R.H.; Zheng, Y.; Weinstein, B.M.; Mukouyama, Y.S.; Gutkind, J.S. Temporalspecific roles of Rac1 during vascular development and retinal angiogenesis. Dev. Biol. 2016, 411, 183-194. [CrossRef]

28. Goel, H.L.; Pursell, B.; Shultz, L.D.; Greiner, D.L.; Brekken, R.A.; Vander Kooi, C.W.; Mercurio, A.M. P-Rex1 Promotes Resistance to VEGF/VEGFR-Targeted Therapy in Prostate Cancer. Cell Rep. 2016, 14, 2193-2208. [CrossRef]

29. Low, I.C.; Loh, T.; Huang, Y.; Virshup, D.M.; Pervaiz, S. Ser70 phosphorylation of Bcl-2 by selective tyrosine nitration of PP2A-B568 stabilizes its antiapoptotic activity. Blood 2014, 124, 2223-2234. [CrossRef]

30. Chong, S.J.F.; Lai, J.X.H.; Qu, J.; Hirpara, J.; Kang, J.; Swaminathan, K.; Loh, T.; Kumar, A.; Vali, S.; Abbasi, T.; et al. A feedforward relationship between active Rac1 and phosphorylated Bcl-2 is critical for sustaining Bcl-2 phosphorylation and promoting cancer progression. Cancer Lett. 2019, 457, 151-167. [CrossRef]

31. Fritsch, R.; de Krijger, I.; Fritsch, K.; George, R.; Reason, B.; Kumar, M.S.; Diefenbacher, M.; Stamp, G.; Downward, J. RAS and RHO families of GTPases directly regulate distinct phosphoinositide 3-kinase isoforms. Cell 2013, 153, 1050-1063. [CrossRef]

32. Yang, H.W.; Shin, M.G.; Lee, S.; Kim, J.R.; Park, W.S.; Cho, K.H.; Meyer, T.; Heo, W.D. Cooperative activation of PI3K by Ras and Rho family small GTPases. Mol. Cell 2012, 47, 281-290. [CrossRef]

33. Bahirwani, R.; Ghabril, M.; Forde, K.A.; Chatrath, H.; Wolf, K.M.; Uribe, L.; Reddy, K.R.; Fuchs, B.; Chalasani, N. Factors that predict short-term intensive care unit mortality in patients with cirrhosis. Clin. Gastroenterol. Hepatol. 2013, 11, 1194-1200.e2. [CrossRef]

34. Lionarons, D.A.; Hancock, D.C.; Rana, S.; East, P.; Moore, C.; Murillo, M.M.; Carvalho, J.; Spencer-Dene, B.; Herbert, E.; Stamp, G.; et al. RAC1. Cancer Cell 2019, 36, 68-83.e69. [CrossRef]

35. Wang, Z.; Fu, M.; Wang, L.; Liu, J.; Li, Y.; Brakebusch, C.; Mei, Q. p21-activated kinase 1 (PAK1) can promote ERK activation in a kinase-independent manner. J. Biol. Chem. 2013, 288, 20093-20099. [CrossRef] [PubMed]

36. Larribère, L.; Cakrapradipta Wibowo, Y.; Patil, N.; Abba, M.; Tundidor, I.; Aguiñón Olivares, R.G.; Allgayer, H.; Utikal, J. NF1-RAC1 axis regulates migration of the melanocytic lineage. Transl. Oncol. 2020, 13, 100858. [CrossRef] [PubMed]

37. Ridley, A.J.; Paterson, H.F.; Johnston, C.L.; Diekmann, D.; Hall, A. The small GTP-binding protein rac regulates growth factorinduced membrane ruffling. Cell 1992, 70, 401-410. [CrossRef] 
38. Sanz-Moreno, V.; Gadea, G.; Ahn, J.; Paterson, H.; Marra, P.; Pinner, S.; Sahai, E.; Marshall, C.J. Rac activation and inactivation control plasticity of tumor cell movement. Cell 2008, 135, 510-523. [CrossRef]

39. Kurisu, S.; Suetsugu, S.; Yamazaki, D.; Yamaguchi, H.; Takenawa, T. Rac-WAVE2 signaling is involved in the invasive and metastatic phenotypes of murine melanoma cells. Oncogene 2005, 24, 1309-1319. [CrossRef]

40. Clayton, N.S.; Ridley, A.J. Targeting Rho GTPase Signaling Networks in Cancer. Front. Cell Dev. Biol. 2020, 8, 222. [CrossRef]

41. Melendez, J.; Memtsa, M.; Stavroulis, A.; Fakokunde, A.; Yoong, W. The best way to determine the best way to undertake a hysterectomy. BJOG 2009, 116, 1539-1540. [CrossRef]

42. Irie, H.Y.; Pearline, R.V.; Grueneberg, D.; Hsia, M.; Ravichandran, P.; Kothari, N.; Natesan, S.; Brugge, J.S. Distinct roles of Akt1 and Akt2 in regulating cell migration and epithelial-mesenchymal transition. J. Cell Biol. 2005, 171, 1023-1034. [CrossRef]

43. Wang, J.; Hirose, H.; Du, G.; Chong, K.; Kiyohara, E.; Witz, I.P.; Hoon, D.S.B. P-REX1 amplification promotes progression of cutaneous melanoma via the PAK1/P38/MMP-2 pathway. Cancer Lett. 2017, 407, 66-75. [CrossRef] [PubMed]

44. Kempers, L.; Driessen, A.J.M.; van Rijssel, J.; Nolte, M.A.; van Buul, J.D. The RhoGEF Trio: A Protein with a Wide Range of Functions in the Vascular Endothelium. Int. J. Mol. Sci. 2021, 22, 10168. [CrossRef] [PubMed]

45. Mohan, A.S.; Dean, K.M.; Isogai, T.; Kasitinon, S.Y.; Murali, V.S.; Roudot, P.; Groisman, A.; Reed, D.K.; Welf, E.S.; Han, S.J.; et al. Enhanced Dendritic Actin Network Formation in Extended Lamellipodia Drives Proliferation in Growth-Challenged Rac1. Dev. Cell 2019, 49, 444-460.e9. [CrossRef] [PubMed]

46. Mani, T.; Hennigan, R.F.; Foster, L.A.; Conrady, D.G.; Herr, A.B.; Ip, W. FERM domain phosphoinositide binding targets merlin to the membrane and is essential for its growth-suppressive function. Mol. Cell Biol. 2011, 31, 1983-1996. [CrossRef]

47. Colón-Bolea, P.; García-Gómez, R.; Shackleton, S.; Crespo, P.; Bustelo, X.R.; Casar, B. RAC1 induces nuclear alterations through the LINC complex to enhance melanoma invasiveness. Mol. Biol. Cell 2020, 31, 2768-2778. [CrossRef]

48. Hanahan, D.; Weinberg, R.A. The hallmarks of cancer. Cell 2000, 100, 57-70. [CrossRef]

49. Baeriswyl, V.; Christofori, G. The angiogenic switch in carcinogenesis. Semin. Cancer Biol. 2009, 19, 329-337. [CrossRef]

50. Lamalice, L.; Le Boeuf, F.; Huot, J. Endothelial cell migration during angiogenesis. Circ. Res. 2007, 100, 782-794. [CrossRef]

51. Dey, N.; Crosswell, H.E.; De, P.; Parsons, R.; Peng, Q.; Su, J.D.; Durden, D.L. The protein phosphatase activity of PTEN regulates SRC family kinases and controls glioma migration. Cancer Res. 2008, 68, 1862-1871. [CrossRef] [PubMed]

52. Price, L.S.; Leng, J.; Schwartz, M.A.; Bokoch, G.M. Activation of Rac and Cdc42 by integrins mediates cell spreading. Mol. Biol. Cell 1998, 9, 1863-1871. [CrossRef]

53. Soga, N.; Connolly, J.O.; Chellaiah, M.; Kawamura, J.; Hruska, K.A. Rac regulates vascular endothelial growth factor stimulated motility. Cell Commun. Adhes. 2001, 8, 1-13. [CrossRef] [PubMed]

54. Tan, W.; Palmby, T.R.; Gavard, J.; Amornphimoltham, P.; Zheng, Y.; Gutkind, J.S. An essential role for Rac1 in endothelial cell function and vascular development. FASEB J. 2008, 22, 1829-1838. [CrossRef] [PubMed]

55. Liu, H.; Rigamonti, D.; Badr, A.; Zhang, J. Ccm1 regulates microvascular morphogenesis during angiogenesis. J. Vasc. Res. 2011, 48, 130-140. [CrossRef] [PubMed]

56. Yamada, S.; Nelson, W.J. Localized zones of Rho and Rac activities drive initiation and expansion of epithelial cell-cell adhesion. J. Cell Biol. 2007, 178, 517-527. [CrossRef]

57. Connolly, J.O.; Simpson, N.; Hewlett, L.; Hall, A. Rac regulates endothelial morphogenesis and capillary assembly. Mol. Biol. Cell 2002, 13, 2474-2485. [CrossRef]

58. Rundhaug, J.E. Matrix metalloproteinases and angiogenesis. J. Cell Mol. Med. 2005, 9, 267-285. [CrossRef]

59. Bryan, B.A.; D'Amore, P.A. What tangled webs they weave: Rho-GTPase control of angiogenesis. Cell Mol. Life Sci. 2007, 64, 2053-2065. [CrossRef]

60. Turcotte, S.; Desrosiers, R.R.; Béliveau, R. HIF-1alpha mRNA and protein upregulation involves Rho GTPase expression during hypoxia in renal cell carcinoma. J. Cell Sci. 2003, 116, 2247-2260. [CrossRef]

61. Draper, J.M.; Smith, C.D. Palmitoyl acyltransferase assays and inhibitors (Review). Mol. Membr. Biol. 2009, 26, 5-13. [CrossRef] [PubMed]

62. Chavda, B.; Arnott, J.A.; Planey, S.L. Targeting protein palmitoylation: Selective inhibitors and implications in disease. Expert Opin. Drug Discov. 2014, 9, 1005-1019. [CrossRef] [PubMed]

63. Bourne, H.R.; Sanders, D.A.; McCormick, F. The GTPase superfamily: Conserved structure and molecular mechanism. Nature 1991, 349, 117-127. [CrossRef] [PubMed]

64. Shutes, A.; Onesto, C.; Picard, V.; Leblond, B.; Schweighoffer, F.; Der, C.J. Specificity and mechanism of action of EHT 1864, a novel small molecule inhibitor of Rac family small GTPases. J. Biol. Chem. 2007, 282, 35666-35678. [CrossRef] [PubMed]

65. Farzaneh Behelgardi, M.; Zahri, S.; Gholami Shahvir, Z.; Mashayekhi, F.; Mirzanejad, L.; Asghari, S.M. Targeting signaling pathways of VEGFR1 and VEGFR2 as a potential target in the treatment of breast cancer. Mol. Biol. Rep. 2020, 47, $2061-2071$. [CrossRef] [PubMed]

66. Vader, P.; van der Meel, R.; Symons, M.H.; Fens, M.H.; Pieters, E.; Wilschut, K.J.; Storm, G.; Jarzabek, M.; Gallagher, W.M.; Schiffelers, R.M.; et al. Examining the role of Rac1 in tumor angiogenesis and growth: A clinically relevant RNAi-mediated approach. Angiogenesis 2011, 14, 457-466. [CrossRef] [PubMed]

67. Ushio-Fukai, M.; Alexander, R.W. Reactive oxygen species as mediators of angiogenesis signaling: Role of NAD(P)H oxidase. Mol. Cell Biochem. 2004, 264, 85-97. [CrossRef] 
68. Yamaoka-Tojo, M.; Ushio-Fukai, M.; Hilenski, L.; Dikalov, S.I.; Chen, Y.E.; Tojo, T.; Fukai, T.; Fujimoto, M.; Patrushev, N.A.; Wang, N.; et al. IQGAP1, a novel vascular endothelial growth factor receptor binding protein, is involved in reactive oxygen species-dependent endothelial migration and proliferation. Circ. Res. 2004, 95, 276-283. [CrossRef]

69. Wang, H.; Ramshekar, A.; Kunz, E.; Sacks, D.B.; Hartnett, M.E. IQGAP1 causes choroidal neovascularization by sustaining VEGFR2-mediated Rac1 activation. Angiogenesis 2020, 23, 685-698. [CrossRef]

70. Bu, F.; Min, J.W.; Munshi, Y.; Lai, Y.J.; Qi, L.; Urayama, A.; McCullough, L.D.; Li, J. Activation of endothelial ras-related C3 botulinum toxin substrate 1 (Rac1) improves post-stroke recovery and angiogenesis via activating Pak1 in mice. Exp. Neurol. 2019, 322, 113059. [CrossRef] [PubMed]

71. Bergers, G.; Hanahan, D. Modes of resistance to anti-angiogenic therapy. Nat. Rev. Cancer 2008, 8, 592-603. [CrossRef]

72. Cannon, A.C.; Uribe-Alvarez, C.; Chernoff, J. RAC1 as a Therapeutic Target in Malignant Melanoma. Trends Cancer 2020, 6 , 478-488. [CrossRef]

73. Cardama, G.A.; Comin, M.J.; Hornos, L.; Gonzalez, N.; Defelipe, L.; Turjanski, A.G.; Alonso, D.F.; Gomez, D.E.; Menna, P.L. Preclinical development of novel Rac1-GEF signaling inhibitors using a rational design approach in highly aggressive breast cancer cell lines. Anticancer Agents Med. Chem. 2014, 14, 840-851. [CrossRef] [PubMed]

74. Tomino, T.; Tajiri, H.; Tatsuguchi, T.; Shirai, T.; Oisaki, K.; Matsunaga, S.; Sanematsu, F.; Sakata, D.; Yoshizumi, T.; Maehara, Y.; et al. DOCK1 inhibition suppresses cancer cell invasion and macropinocytosis induced by self-activating Rac1. Biochem. Biophys. Res. Commun. 2018, 497, 298-304. [CrossRef] [PubMed]

75. Montalvo-Ortiz, B.L.; Castillo-Pichardo, L.; Hernández, E.; Humphries-Bickley, T.; De la Mota-Peynado, A.; Cubano, L.A.; Vlaar, C.P.; Dharmawardhane, S. Characterization of EHop-016, novel small molecule inhibitor of Rac GTPase. J. Biol. Chem. 2012, 287, 13228-13238. [CrossRef]

76. Castillo-Pichardo, L.; Humphries-Bickley, T.; De La Parra, C.; Forestier-Roman, I.; Martinez-Ferrer, M.; Hernandez, E.; Vlaar, C.; Ferrer-Acosta, Y.; Washington, A.V.; Cubano, L.A.; et al. The Rac Inhibitor EHop-016 Inhibits Mammary Tumor Growth and Metastasis in a Nude Mouse Model. Transl. Oncol. 2014, 7, 546-555. [CrossRef]

77. Russell, R.G. Bisphosphonates: The first 40 years. Bone 2011, 49, 2-19. [CrossRef]

78. Ferri, N.; Contini, A.; Bernini, S.K.; Corsini, A. Role of small GTPase protein Rac1 in cardiovascular diseases: Development of new selective pharmacological inhibitors. J. Cardiovasc. Pharmacol. 2013, 62, 425-435. [CrossRef]

79. Gao, Y.; Dickerson, J.B.; Guo, F.; Zheng, J.; Zheng, Y. Rational design and characterization of a Rac GTPase-specific small molecule inhibitor. Proc. Natl. Acad. Sci. USA 2004, 101, 7618-7623. [CrossRef] [PubMed]

80. Bouquier, N.; Vignal, E.; Charrasse, S.; Weill, M.; Schmidt, S.; Léonetti, J.P.; Blangy, A.; Fort, P. A cell active chemical GEF inhibitor selectively targets the Trio/RhoG/Rac1 signaling pathway. Chem. Biol. 2009, 16, 657-666. [CrossRef]

81. Ferri, N.; Corsini, A.; Bottino, P.; Clerici, F.; Contini, A. Virtual screening approach for the identification of new Rac1 inhibitors. J. Med. Chem. 2009, 52, 4087-4090. [CrossRef]

82. Xie, W.; Zhang, W.; Sun, M.; Lu, C.; Shen, Y. Deacetylmycoepoxydiene is an agonist of Rac1, and simultaneously induces autophagy and apoptosis. Appl. Microbiol. Biotechnol. 2018, 102, 5965-5975. [CrossRef]

83. Dütting, S.; Heidenreich, J.; Cherpokova, D.; Amin, E.; Zhang, S.C.; Ahmadian, M.R.; Brakebusch, C.; Nieswandt, B. Critical off-target effects of the widely used Rac1 inhibitors NSC23766 and EHT1864 in mouse platelets. J. Thromb. Haemost. 2015, 13, 827-838. [CrossRef]

84. Abdrabou, A.; Wang, Z. Post-Translational Modification and Subcellular Distribution of Rac1: An Update. Cells 2018, 7, 263. [CrossRef] [PubMed]

85. Miller, T.; Yang, F.; Wise, C.E.; Meng, F.; Priester, S.; Munshi, M.K.; Guerrier, M.; Dostal, D.E.; Glaser, S.S. Simvastatin stimulates apoptosis in cholangiocarcinoma by inhibition of Rac1 activity. Dig. Liver Dis. 2011, 43, 395-403. [CrossRef]

86. Navarro-Lerida, I.; Sanchez-Perales, S.; Calvo, M.; Rentero, C.; Zheng, Y.; Enrich, C.; Del Pozo, M.A. A palmitoylation switch mechanism regulates Rac1 function and membrane organization. EMBO J. 2012, 31, 534-551. [CrossRef] [PubMed]

87. Uribe-Alvarez, C.; Guerrero-Rodríguez, S.L.; Rhodes, J.; Cannon, A.; Chernoff, J.; Araiza-Olivera, D. Targeting effector pathways in RAC1. Small GTPases 2021, 12, 273-281. [CrossRef]

88. Lu, J.; Chan, L.; Fiji, H.D.G.; Dahl, R.; Kwon, O.; Tamanoi, F. In vivo antitumor effect of a novel inhibitor of protein geranylgeranyltransferase-I. Mol. Cancer Ther. 2009, 8, 1218-1226. [CrossRef] [PubMed]

89. Zimonjic, D.B.; Chan, L.N.; Tripathi, V.; Lu, J.; Kwon, O.; Popescu, N.C.; Lowy, D.R.; Tamanoi, F. In vitro and in vivo effects of geranylgeranyltransferase I inhibitor P61A6 on non-small cell lung cancer cells. BMC Cancer 2013, 13, 198. [CrossRef] [PubMed]

90. Khan, O.M.; Ibrahim, M.X.; Jonsson, I.M.; Karlsson, C.; Liu, M.; Sjogren, A.K.; Olofsson, F.J.; Brisslert, M.; Andersson, S.; Ohlsson, C.; et al. Geranylgeranyltransferase type I (GGTase-I) deficiency hyperactivates macrophages and induces erosive arthritis in mice. J. Clin. Investig. 2011, 121, 628-639. [CrossRef] [PubMed]

91. Ochocki, J.D.; Distefano, M.D. Prenyltransferase Inhibitors: Treating Human Ailments from Cancer to Parasitic Infections. Medchemcomm 2013, 4, 476-492. [CrossRef]

92. Ferri, N.; Colombo, G.; Ferrandi, C.; Raines, E.W.; Levkau, B.; Corsini, A. Simvastatin reduces MMP1 expression in human smooth muscle cells cultured on polymerized collagen by inhibiting Rac1 activation. Arterioscler Thromb. Vasc. Biol. 2007, 27, 1043-1049. [CrossRef] 
93. Tanaka, S.; Fukumoto, Y.; Nochioka, K.; Minami, T.; Kudo, S.; Shiba, N.; Takai, Y.; Williams, C.L.; Liao, J.K.; Shimokawa, H. Statins exert the pleiotropic effects through small GTP-binding protein dissociation stimulator upregulation with a resultant Rac1 degradation. Arterioscler Thromb. Vasc. Biol. 2013, 33, 1591-1600. [CrossRef]

94. Michaelson, D.; Silletti, J.; Murphy, G.; D’Eustachio, P.; Rush, M.; Philips, M.R. Differential localization of Rho GTPases in live cells: Regulation by hypervariable regions and RhoGDI binding. J. Cell Biol. 2001, 152, 111-126. [CrossRef]

95. Marei, H.; Malliri, A. Rac1 in human diseases: The therapeutic potential of targeting Rac1 signaling regulatory mechanisms. Small GTPases 2017, 8, 139-163. [CrossRef]

96. Humphries-Bickley, T.; Castillo-Pichardo, L.; Hernandez-O’Farrill, E.; Borrero-Garcia, L.D.; Forestier-Roman, I.; Gerena, Y.; Blanco, M.; Rivera-Robles, M.J.; Rodriguez-Medina, J.R.; Cubano, L.A.; et al. Characterization of a Dual Rac/Cdc42 Inhibitor MBQ-167 in Metastatic Cancer. Mol. Cancer Ther. 2017, 16, 805-818. [CrossRef] [PubMed]

97. Rudolph, J.; Murray, L.J.; Ndubaku, C.O.; O’Brien, T.; Blackwood, E.; Wang, W.; Aliagas, I.; Gazzard, L.; Crawford, J.J.; Drobnick, J.; et al. Chemically Diverse Group I p21-Activated Kinase (PAK) Inhibitors Impart Acute Cardiovascular Toxicity with a Narrow Therapeutic Window. J. Med. Chem. 2016, 59, 5520-5541. [CrossRef] [PubMed]

98. Bosco, E.E.; Kumar, S.; Marchioni, F.; Biesiada, J.; Kordos, M.; Szczur, K.; Meller, J.; Seibel, W.; Mizrahi, A.; Pick, E.; et al. Rational design of small molecule inhibitors targeting the Rac GTPase-p67(phox) signaling axis in inflammation. Chem. Biol. 2012, 19, 228-242. [CrossRef] [PubMed]

99. Lisabeth, E.M.; Kahl, D.; Gopallawa, I.; Haynes, S.E.; Misek, S.A.; Campbell, P.L.; Dexheimer, T.S.; Khanna, D.; Fox, D.A.; Jin, X.; et al. Identification of Pirin as a Molecular Target of the CCG-1423/CCG-203971 Series of Antifibrotic and Antimetastatic Compounds. ACS Pharmacol. Transl. Sci. 2019, 2, 92-100. [CrossRef] [PubMed]

100. Licciulli, S.; Luise, C.; Scafetta, G.; Capra, M.; Giardina, G.; Nuciforo, P.; Bosari, S.; Viale, G.; Mazzarol, G.; Tonelli, C.; et al. Pirin inhibits cellular senescence in melanocytic cells. Am. J. Pathol. 2011, 178, 2397-2406. [CrossRef]

101. Miyazaki, I.; Simizu, S.; Okumura, H.; Takagi, S.; Osada, H. A small-molecule inhibitor shows that pirin regulates migration of melanoma cells. Nat. Chem. Biol. 2010, 6, 667-673. [CrossRef]

102. Van Allen, E.M.; Wagle, N.; Sucker, A.; Treacy, D.J.; Johannessen, C.M.; Goetz, E.M.; Place, C.S.; Taylor-Weiner, A.; Whittaker, S.; Kryukov, G.V.; et al. The genetic landscape of clinical resistance to RAF inhibition in metastatic melanoma. Cancer Discov. 2014, 4 , 94-109. [CrossRef]

103. Hayashi, K.; Watanabe, B.; Nakagawa, Y.; Minami, S.; Morita, T. RPEL proteins are the molecular targets for CCG-1423, an inhibitor of Rho signaling. PLoS ONE 2014, 9, e89016. [CrossRef]

104. Lundquist, M.R.; Storaska, A.J.; Liu, T.C.; Larsen, S.D.; Evans, T.; Neubig, R.R.; Jaffrey, S.R. Redox modification of nuclear actin by MICAL-2 regulates SRF signaling. Cell 2014, 156, 563-576. [CrossRef] [PubMed]

105. Hutchings, K.M.; Lisabeth, E.M.; Rajeswaran, W.; Wilson, M.W.; Sorenson, R.J.; Campbell, P.L.; Ruth, J.H.; Amin, A.; Tsou, P.S.; Leipprandt, J.R.; et al. Pharmacokinetic optimitzation of CCG-203971: Novel inhibitors of the Rho/MRTF/SRF transcriptional pathway as potential antifibrotic therapeutics for systemic scleroderma. Bioorg. Med. Chem. Lett. 2017, 27, 1744-1749. [CrossRef] [PubMed]

106. Hino, R.; Kabashima, K.; Kato, Y.; Yagi, H.; Nakamura, M.; Honjo, T.; Okazaki, T.; Tokura, Y. Tumor cell expression of programmed cell death-1 ligand 1 is a prognostic factor for malignant melanoma. Cancer 2010, 116, 1757-1766. [CrossRef] [PubMed] 